\title{
FAKTOR PREDISPOSISI TINGGINYA PENGGUNA KB SUNTIK PADA PASANGAN USIA SUBUR (PUS) DI DESA CIHIDEUNG HILIR KECAMATAN CIDAHU KABUPATEN KUNINGAN
}

\author{
${ }^{1}$ Nova Winda Setiati, ${ }^{2}$ Imas Sihabul Milah \\ ${ }^{1,2}$ STIKes Kuningan \\ novawindasetiati@gmail.com
}

\begin{abstract}
Abstrak
Keluarga Berencana merupakan program pemerintah untuk mengendalikan populasi penduduk Indonesia. Berdasarkan profil kesehatan Dinas Kesehatan Kabupaten Kuningan, dilaporkan Kecamatan Cidahu paling banyak menggunakan KB suntik sebanyak 5407 dan desa yang paling tinggi pengguna $\mathrm{KB}$ suntik yaitu desa Cihideung Hilir sebanyak 821 orang $(15,18 \%)$. Tujuan penelitian ini untuk mengetahui faktor predisposisi tingginya penggunaan KB suntik di Desa Cihideung Hilir Kecamatan Cidahu Kabupaten Kuningan Tahun 2019. Jenis penelitian ini deskriptif dengan rancangan observasional. Jumlah populasi 821 orang, dengan teknik pengambilan sampel secara stratified random sampling dengan rumus slovin besar sampel 269 orang. Instrumen untuk memperoleh data menggunakan kuesioner. Data penelitian bersifat primer, dan menggunakan analisa secara univariat. Hasil penelitian menunjukan responden yang mendapat dukungan suami berjumlah 230 orang $(85,5 \%)$, responden lebih banyak berumur 20-35 tahun berjumlah 157 orang $(58,4 \%)$, responden memiliki pengetahuan kurang berjumlah 123 orang (45,7\%), serta responden memiliki latar belakang pendidikan dasar berjumlah 113 orang $(42,0 \%)$. Kesimpulan dari penelitian ini bahwa faktor predisposisi tingginya penggunaan KB suntik adalah pendidikan, pengetahuan, umur, dan dukungan suami.
\end{abstract}

Kata Kunci : KB Suntik, Akseptor, Faktor Predisposisi

Pendahuluan

Indonesia merupakan salah satu negara berkembang dengan masalah ledakan jumlah penduduk yang beberapa tahun terakhir ini sulit terkontrol. Secara garis besar masalah pokok dibidang kependudukan yang dihadapi Indonesia adalah jumlah pertumbuhan penduduk yang besar dengan laju pertumbuhan pendudukyang relatif masih tinggi, 
JOURNAL OF MIDWIFERY CARE :

VOL. 01 NO. 01, DESEMBER 2020

DOI : $10.34305 /$ jmc.v1i1.188
Ciptaan disebarluaskan di bawah

Lisensi Creative Commons

Atribusi-NonKomersial-

BerbagiSerupa 4.0 Internasional. penyebaran penduduk yang tidak merata, struktur umur muda, dan kualitas penduduk yang masih harus ditingkatkan. Menurut Runjati \& Syahrial Umar, (2018, p. 657) salah satu upaya untuk menurunkan tingkat pertumbuhan penduduk adalah melalui pengendalian fertilitas yang instrumen utamanya adalah Program Keluarga Berencana. Menurut Rastyawati, (2011, p. 31) keluarga berencana dirumuskan sebagai upaya peningkatan kepedulian peran serta masyarakat melalui batas usia perkawinan, pengaturan kelahiran, pembinaan ketahanan keluarga untuk mewujudkan keluarga kecil bahagia dan sejahtera.

Menurut World Health Organization (WHO) dalam Runjati \& Syahrial Umar, (2018, p. 667) pada tahun 2015 penggunaan kontrasepsi telah meningkat di berbagai dunia, terutama di Asia dan Amerika Latin dan terendah di Sub-Sahara Afrika. Secara global, penggunaan kontrasepsi modern telah meningkat tidak signifikan dari $54 \%$ pada tahun 1990 menjadi $57,4 \%$ pada tahun 2015. Secara regional, proporsi pasangan usia subur 15-49 tahun melaporkan penggunaan metode kontrasepsi modern telah meningkat minimal 6 tahun terakhir. Di Afrika dari 23,6\% menjadi 27,6\%, di Asia telah meningkat dari $60,9 \%$ menjadi $61,6 \%$, sedangkan Amerika Latin dan Karibia naik sedikit dari $66,7 \%$ menjadi $67,0 \%$.

Hasil sensus penduduk tahun 2016 menunjukkan penduduk Indonesia berjumlah 254,7 juta jiwa. Indonesia menempati urutan keempat negara berpenduduk terbanyak di dunia setelah Tiongkok, India, dan Amerika Serikat. Penduduk Indonesia diproyeksikan berjumlah 261,9 juta jiwa pada tahun 2017. Laju Pertumbuhan Penduduk (LPP) diproyeksikan menurun dari 1,49\%/tahun pada periode tahun 2000-2010 menjadi 1,38\%/tahun pada kurun tahun 2010-2015, lalu menjadi 1,19\%/tahun pada periode tahun 2015-2020. Total Fertility Rate (TFR) tertahan di angka 2,6 sesuai hasil Survei Demografi dan Kesehatan Indonesia SDKI, (2007-2012). Dari data Badan Keluarga Berencana dan Pemberdayaan Perempuan (BKBPK), di Jawa Barat laju pertumbuhan penduduk sebesar 1,64\%, di Kuningan laju pertumbuhan penduduk mencapai $0,46 \%$, untuk TFR 2,46\%.

Berdasarkan hasil Riskesdas (2015), penggunaan metode kontrasepsi didominasi oleh metode kontrasepsi modern $(59,3 \%)$. Hasil survei peserta KB aktif di Indonesia tahun 2015 menunjukkan kontrasepsi suntik masih menjadi pilihan utama pada pasangan usia subur. 
JOURNAL OF MIDWIFERY CARE :

VOL. 01 NO. 01, DESEMBER 2020

DOI : $10.34305 /$ jmc.v1i1.188
Ciptaan disebarluaskan di bawah

Lisensi Creative Commons

Atribusi-NonKomersial-

BerbagiSerupa 4.0 Internasional.
Cakupan penggunaan $\mathrm{KB}$ suntik mengalami kenaikan dari tahun 2014 sebanyak $46,87 \%$ menjadi $53,80 \%$ pada tahun 2015, ini menunjukan kenaikan cakupan penggunaan KB suntik sebanyak 6,93\% dari tahun 2014-2015. Cakupan penggunaan alat kontrasepsi lain yaitu Pil sebanyak $24,54 \%$ pada tahun 2014 menjadi $28,30 \%$ di tahun 2015, IUD sebanyak 11,41\%pada tahun 2014 menjadi 6,79\% di tahun 2015, Implan sebanyak 9,75\% pada tahun 2014 menjadi 21,99\% di tahun 2015, MOW sebanyak 3,52\% pada tahun 2014 menjadi $5,59 \%$ di tahun 2015, MOP sebanyak $0,69 \%$ menjadi $0,49 \%$ di tahun 2015, Kondom sebanyak 3,22\% pada tahun 2014 menjadi 3,69\% di tahun 2015. Dari data yang diperoleh dari BKBPP jumlah akseptor KB suntik yaitu sebanyak 15.420 akseptor, adapun data yang didapatkan dari Dinas Kesehatan Kabupaten Kuningan (2017) tercatat peserta KB suntik pada tahun 2017 yang terbanyak yaitu kecamatan Cidahu.

Beberapa faktor yang berpengaruh terhadap pemilihan metode kontrasepsi yang digunakan yaitu faktor predisposisi (umur, pendidikan, jumlah anak, pengetahuan, sikap), faktor pendukung (ketersediaan alat kontrasepsi, jarak rumah ke puskesmas, waktu tempuh dan biaya), faktor pendorong (dukungan petugas kesehatan dan keluarga). Pendidikan dan pengetahuan akseptor KB suntik mempengaruhi terhadap pemilihan atau penggunaan KB suntik (Purba, 2009, p. $67)$.

Pemerintah terus berupaya menekan laju pertumbuhan dengan program keluarga berencana. Salah satunya dengan mencanangkan program Keluarga Berencana (KB) yang dimulai sejak tahun 1970. Keluarga berencana merupakan usaha untuk mengukur jumlah anak dan jarak kelahiran anak yang diinginkan. Maka dari itu, Pemerintah mencanangkan program atau cara untuk mencegah dan menunda kehamilan (Handayani, 2010, p. 29).

Hasil penelitian yang telah dilakukan oleh Esra, (2017) terhadap faktor-faktor yang mempengaruhi penyebab tingginya akseptor KB suntik menyimpulkan bahwa berdasarkan tingkat pengetahuan ibu yaitu cukup sebesar (63,51\%), berdasarkan pengalaman ibu yaitu atas kemauan sendiri sebesar $(75,68 \%)$, berdasarkan dukungan suami yaitu sebesar (100\%) suami mendukung istri dalam memilih alat kontrasepsi, berdasarkan keterjangkauan pelayanan yaitu mudah diperoleh sebesar $(39,19 \%)$, dan hasil penelitian yang dilakukan oleh Regina Mitha Jacobus, (2018) terhadap faktor-faktor yang 
JOURNAL OF MIDWIFERY CARE :

VOL. 01 NO. 01, DESEMBER 2020

DOI : $10.34305 /$ jmc.v1i1.188
Ciptaan disebarluaskan di bawah

Lisensi Creative Commons

Atribusi-NonKomersial-

BerbagiSerupa 4.0 Internasional. berhubungan dengan penggunaan alat kontrasepsi suntik, hasil uji statistik menunjukkan variabel yang berhubungan dengan penggunaan alat kontrasepsi suntik yaitu umur $(\mathrm{p}$-value $=0,044)$ dan pengetahuan $(p$-value $=0,002)$, adapun variabel yang tidak berhubungan dengan penggunaan alat kontrasepsi suntik adalah sikap $)$ p-value $=0,517)$. Hasil penelitian yang dilakukan oleh (Kurniawan, 2016) terhadap faktor-faktor yang mempengaruhi tingginya penggunaan alat kontrasepsi suntik, dengan hasil penelitian menunjukkan $26,2 \%$ akseptor tidak memilih alat kontrasepsi suntik dan $73,8 \%$ akseptor memilih alat kontrasepsi suntik, analisis bivariat menunjukkan bahwa faktor yang memengaruhi pemilihan alat kontrasepsi suntik adalah umur $(p<0,05)$, pengetahuan $(\mathrm{p}<0,05)$, dan sosial budaya $(\mathrm{p}<0,05)$, adapun pendidikan tidak memengaruhi pemilihan alat kontrasepsi suntik ( $p>0,05)$.

Dari hasil studi pendahuluan yang telah dilakukan pada tanggal 05-06 Januari 2019 di Kecamatan Cidahu Kabupaten Kuningan pada 60 orang responden dengan cara wawancara di Kecamatan Cidahu Kabupaten Kuningan didapatkan hasil bahwa faktor predisposisi pada tingginya penggunaan $\mathrm{KB}$ suntik di wilayah kerja UPTD Puskesmas Cidahu Kecamatan
Cidahu Kabupaten Kuningan Tahun 2019 yaitu kecocokan dalam pemakaian KB suntik (12\%), pengalaman yang lalu (8\%), pengetahuan terhadap alat kontrasepsi lain rendah (20\%), dukungan suami (17\%), umur (18\%), ketakutan menggunakan alat kontrasepsi lain (10\%), mengikuti orang sekitar/lingkungan sekitar (15\%).

Berdasarkan uraian diatas penulis tertarik melakukan penelitian tentang Faktor Predisposisi Tingginya Pengguna KB Suntik Pada Pasangan Usia Subur (PUS) di Desa Cihideung Hilir Kecamatan Cidahu Kabupaten Kuningan Tahun 2019.

\section{Metode}

Jenis penelitian yang digunakan oleh peneliti adalah deskriptif dengan rancangan observasional. Dalam penelitian ini yang menjadi populasi adalah seluruh pengguna KB suntik di Desa Cihideung Hilir Kecamatan Cidahu Kabupaten Kuningan Pada Tahun 2018 yaitu sebanyak 821 orang. Sampel berjumlah 269 orang. Pengambilan sampel dalam penelitian ini menggunakan metode stratified random sampling. Variabel bebas dalam penelitian ini adalah pendidikan, pengetahuan, umur, dukungan suami. Variabel terikatnya adalah akseptor KB suntik yang ada di Desa Cihideung Hilir 
JOURNAL OF MIDWIFERY CARE :

VOL. 01 NO. 01, DESEMBER 2020

DOI : $\underline{10.34305 / j m c . v 1 i 1.188}$
Ciptaan disebarluaskan di bawah

Lisensi Creative Commons

Atribusi-NonKomersial-

BerbagiSerupa 4.0 Internasional.

Kecamatan Cidahu Kabupaten Kuningan.

Analisa yang digunakan analisis univariat.

\section{Hasil}

Tabel 1. Distribusi Frekuensi Akseptor KB Suntik

\begin{tabular}{lcc}
\hline \multicolumn{1}{c}{ Variabel } & Frekuensi & Presentase (\%) \\
\hline Pendidikan & & 42,0 \\
\hline Dasar & 113 & 35,0 \\
Menengah Pertama & 94 & 20,4 \\
Menengah atas & 55 & 2,6 \\
Perguruan tinggi & 7 & 100 \\
Jumlah & 269 & \\
\hline Pengetahuan & & 45,7 \\
\hline Kurang & 123 & 36,1 \\
Sedang & 97 & 18,2 \\
Baik & 49 & 100 \\
Jumlah & 269 & 4,1 \\
\hline Umur & & 58,4 \\
\hline$<20$ Tahun & 11 & 37,5 \\
20-35 Tahun & 157 & 100 \\
$>35$ Tahun & 101 & 85,5 \\
Jumlah & 269 & 14,5 \\
\hline Dukungan Suami & & 100 \\
\hline Mendukung & 230 & 24,9 \\
Tidak Mendukung & 39 & 75,1 \\
Jumlah & 269 & 100 \\
\hline Akseptor KB Suntik & & \\
\hline Suntik 1 Bulan & 67 & \\
Suntik 3 Bulan & 202 & \\
Jumlah & 269 & \\
\hline & & \\
\hline
\end{tabular}

Sumber : Penelitian Tahun 2019.

Berdasarkan Tabel 1 dapat dilihat bahwa dari 269 responden yang diteliti, paling banyak responden berpendidikan dasar yaitu sebanyak 113 orang atau 42,0\%. Selanjutnya pada variabel pengetahuan paling banyak responden memiliki pengetahuan kurang yaitu sebanyak 123 orang atau $45,7 \%$. Umur responden paling banyak 20-35 tahun yaitu sebanyak 157 orang atau 58,4\%. Dan 230 orang atau $85,50 \%$ akseptor $\mathrm{KB}$ suntik mendapatkan dukungan suami. Serta jumlah responden paling banyak menggunakan $\mathrm{KB}$ suntik 3 bulan yaitu sebanyak 202 orang atau $75,1 \%$ dari seluruh responden. 
JOURNAL OF MIDWIFERY CARE :

VOL. 01 NO. 01, DESEMBER 2020

DOI : $10.34305 /$ jmc.v1i1.188
Ciptaan disebarluaskan di bawah

Lisensi Creative Commons

Atribusi-NonKomersial-

BerbagiSerupa 4.0 Internasional.

Tabel 2. Distribusi Gambaran Penggunaan KB Suntik Pada Pasangan Usia Subur (PUS)

\begin{tabular}{|c|c|c|c|c|c|c|}
\hline \multirow{3}{*}{ Variabel } & \multicolumn{4}{|c|}{ Akseptor KB Suntik } & & \\
\hline & \multicolumn{2}{|c|}{ Suntik 1 Bulan } & \multicolumn{2}{|c|}{ Suntik 3 Bulan } & \multicolumn{2}{|c|}{ Total } \\
\hline & $\mathbf{F}$ & $\%$ & $\mathbf{F}$ & $\%$ & $\mathbf{F}$ & $\%$ \\
\hline \multicolumn{7}{|l|}{ Pendidikan } \\
\hline Dasar & 0 & 0,0 & 113 & 100 & 113 & 100 \\
\hline Menengah Pertama & 5 & 5,3 & 89 & 94,7 & 94 & 100 \\
\hline Menengah Atas & 55 & 100 & 0 & 0,00 & 55 & 100 \\
\hline Perguruan Tinggi & 7 & 100 & 0 & 0,00 & 7 & 100 \\
\hline \multicolumn{7}{|l|}{ Pengetahuan } \\
\hline Kurang & 0 & 0,0 & 123 & 100 & 123 & 100 \\
\hline Sedang & 18 & 18,6 & 79 & 81,4 & 97 & 100 \\
\hline Baik & 49 & 100 & 0 & 0,00 & 49 & 100 \\
\hline \multicolumn{7}{|l|}{ Umur } \\
\hline$<20$ Tahun & 0 & 0,00 & 11 & 100 & 11 & 100 \\
\hline 20-35 Tahun & 0 & 0,00 & 157 & 100 & 157 & 100 \\
\hline$>35$ Tahun & 67 & 66,3 & 34 & 33,7 & 101 & 100 \\
\hline \multicolumn{7}{|l|}{ Dukungan Suami } \\
\hline Mendukung & 28 & 12,2 & 202 & 87,8 & 230 & 100 \\
\hline Tidak Mendukung & 39 & 100 & 0 & 0,00 & 39 & 100 \\
\hline
\end{tabular}

Sumber : Penelitian Tahun 2019

Berdasarkan Tabel 2 dapat dilihat dari 113 responden dengan pendidikan dasar $100 \%$ terdapat pada suntik 3 bulan, dari 94 responden dengan pendidikan menengah pertama hampir seluruhnya menggunakan KB suntik 3 bulan yaitu sebanyak 94,7\%, dari 55 responden dengan pendidikan menengah atas 100\% menggunakan KB suntik 1 bulan, dari 7 responden dengan pendidikan tinggi 100\% menggunakan KB suntik 1 bulan. Selanjutnya dari 123 responden yang memiliki pengetahuan kurang $100 \%$ terdapat pada pengguna $\mathrm{KB}$ suntik 3 bulan, dari 97 responden yang memiliki pengetahuan sedang hampir seluruhnya yaitu sebanyak $81,4 \%$ pada pengguna KB suntik 3 bulan, dari 49 yang memiliki pengetahuan baik $100 \%$ terdapat pada pengguna KB suntik 1 bulan. Kemudian dari 11 responden dengan umur $<20$ tahun $100 \%$ berada pada pengguna KB suntik 3 bulan, dari 157 responden dengan umur 20-35 tahun 100\% berada pada pengguna KB suntik 3 bulan, dari 101 responden dengan umur $>35$ tahun hampir seluruhnya yaitu $66,3 \%$ berada pada pengguna KB suntik 1 bulan. Selanjutnya dari 230 responden yang mendapat dukungan suami hampir seluruhnya berada pada pengguna KB suntik 3 bulan yaitu sebanyak 87,8\%, dari 39 responden yang tidak mendapatkan dukungan suami 100\% berada pada pengguna KB suntik 1 bulan. 
JOURNAL OF MIDWIFERY CARE :

VOL. 01 NO. 01, DESEMBER 2020

DOI : $10.34305 /$ jmc.v1i1.188
Ciptaan disebarluaskan di bawah

Lisensi Creative Commons

Atribusi-NonKomersial-

BerbagiSerupa 4.0 Internasional.

\section{Pembahasan}

Tabel 1 menunjukkan responden sebagian besar ibu berpendidikan dasar sebanyak 113 orang atau 42,0\%. Menurut teori Hurlock, (2008, p. 59) pendidikan berperan penting dalam menentukan kualitas manusia. Hasil ini menggambarkan bahwa kualitas masyarakat masih kurang, sebanyak 42,0\%. Hasil pengamatan langsung pada saat penyebaran kuesioner didapat faktor ekonomi dan lingkungan sekitar yang menjadi penyebab ibu memiliki pendidikan hanya sampai SD saja. Pendidikan merupakan proses menumbuh kembangkan seluruh kemampuan dari perilaku manusia melalui pengetahuan, sehingga dalam pendidikan perlu dipertimbangkan umur (proses perkembangan klien) dan hubungan dengan proses belajar. Menurut Nugroho \& Utama I.B, (2014, p. 49) tingkat pendidikan juga merupakan salah satu faktor yang mempengaruhi persepsi seseorang untuk lebih mudah menerima ide-ide teknologi.

$$
\text { Selanjutnya pada variabel }
$$
perempuan sebagian besar ibu berpengetahuan kurang, hal ini menunjukkan masih banyak faktor yang mempengaruhi pengetahuan yang belum ibu miliki, karena pendidikan ibu hanya sampai SD. Riyanto, (2014, p. 101) mengemukakan bahwa faktor yang mempengaruhi pengetahuan adalah pendidikan, informasi dan tingkatan masing-masing individu berbeda-beda tergantung dari individu itu sendiri. Menurut Notoatmodjo, (2012, p. 112) semakin tinggi tingkat pendidikan seseorang, maka akan semakin mudah untuk menerima serta mengembangkan pengetahuan dan teknologi, dan semakin tinggi tingkat pengetahuan seseorang, maka akan semakin mudah untuk menerima informasi tentang objek atau yang berkaitan dengan pengetahuan. Pengetahuan yang kurang ini perlu diadakannya suatu perbaikan dan peningkatan melalui pendekatan yang intensif dari petugas kesehatan kepada masyarakat dalam memberikan pengertian tentang KB.

Hasil penelitian juga menunjukkan sebagian besar responden berusia 20-35 tahun. Menurut World Health Organization (WHO) dalam Anggraini, Y. (2011, p. 197) umur reproduksi yang sehat dan aman adalah 20-35 tahun, pada umur $<20$ tahun secara biologis belum optimal emosinya cenderung labil, mentalnya belum matang. Pada umur >35 tahun terkait dengan kemunduran dan penurunan daya tahan tubuh serta berbagai penyakit yang sering menimpa pada umur ini.

Menurut Hartanto (2010, p. 69) umur 20 tahun sampai 35 tahun merupakan usia 
JOURNAL OF MIDWIFERY CARE :

VOL. 01 NO. 01, DESEMBER 2020

DOI : $10.34305 /$ jmc.v1i1.188
Ciptaan disebarluaskan di bawah

Lisensi Creative Commons

Atribusi-NonKomersial-

BerbagiSerupa 4.0 Internasional. produktif, merupakan usia yang optimal dalam menerima informasi dari lingkungan melalui panca indera dan masih kuatnya daya ingat seseorang yang dapat mempengaruhi pengetahuan. Pada umur lebih dari 35 tahun daya ingat dan daya nalar seseorang sudah mulai berkurang disebabkan kemampuan otak sudah mulai mengalami kemunduran. Daya ingat yang menurun akan menyebabkan berkurangnya pengetahuan yang didapatkan, apalagi untuk menerima informasi dari lingkungan, umur adalah usia individu yang terhitung mulai saat dilahirkan.

Menurut Wiknjosastro H (2009, p. 23) umur ibu dianggap penting karena dapat menerima beberapa nilai seperti pengalaman, perkembangan berpikir, dan kemampuan adalah nilai-nilai tertentu seorang wanita yang sudah memiliki umur reproduksi sehat. Dari hasil penelitian pada usia 20-35 tahun lebih banyak menggunakan $\mathrm{KB}$ suntik daripada alat kontrasepsi lain dikarenakan lingkungan sekitar, ketakutan menggunakan alat kontrasepsi lain, dan meyakini bahwa KB suntik yang paling praktis dibandingkan dengan alat kontrasepsi, mendapat informasi seadanya, kurang mengetahui tentang alat kontrasepsi lain, kenyamanan terhadap kontrasepsi suntik. Dari hasil penelitian masyarakat kebanyakan menggunakan alat kontrasepsi karena pengaruh lingkungan sekitar, misalnya melihat orang-orang yang lebih tua atau yang lebih berpengalaman lebih dahulu menggunakan $\mathrm{KB}$ suntik.

Dukungan sosial dan psikologis sangat diperlukan oleh setiap individu di dalam setiap siklus kehidupan, dukungan sosial akan semakin dibutuhkan pada saat seseorang sedang menghadapi masalah atau sakit, disinilah peran anggota keluarga diperlukan untuk menjalani masa-masa sulit dengan cepat.

Menurut Runjati \& Syahrial Umar (2018, p. 657) dukungan keluarga dikelompokkan menjadi empat yaitu dukungan emosional, dukungan nyata, dukungan informasi dan dukungan pengharapan, dukungan internal (suami) merupakan aspek yang penting untuk peningkatan kesehatan reproduksi. Dukungan suami menurut Efendi et al. (2009, p. 157) peran dan tanggung jawab suami dalam kesehatan reproduksi khususnya pada keluarga berencana adalah peran suami sebagai motivator, edukator, fasilitator.

Alasan responden lebih dominan menggunakan KB suntik 3 bulan dikarenakan alasan ekonomi, efek samping KB dan kepraktisan pelaksanaan KB suntik 
JOURNAL OF MIDWIFERY CARE :

VOL. 01 NO. 01, DESEMBER 2020

DOI : $10.34305 /$ jmc.v1i1.188

3 bulan yaitu lebih lama untuk kunjungan ulang KB suntik 3 bulan daripada KB suntik 1 bulan.

Selanjutnya responden dengan pendidikan menengah pertama hampir seluruhnya menggunakan KB suntik 3 bulan yaitu sebanyak 94,7\%, dari 55 responden dengan pendidikan menengah atas $100 \%$ menggunakan $\mathrm{KB}$ suntik 1 bulan, dari 7 responden dengan pendidikan tinggi $100 \%$ menggunakan $\mathrm{KB}$ suntik 1 bulan.

Dari hasil penelitian yang didapatkan ini karena pengetahuan akseptor KB suntik yang masih rendah dan menggunakan salah satu alat kontrasepsi karena lingkungan sekitar. Hal ini sesuai dengan pendapat Wawan \& Dewi (2010, p. 17) pendidikan mempengaruhi proses belajar, semakin tinggi pendidikan seseorang semakin mudah orang tersebut menerima informasi. Menurut Hurlock (2008, p. 59) pendidikan memiliki peranan penting dalam menentukan kualitas manusia, dengan pendidikan manusia dianggap akan memperoleh pengetahuan. Akseptor KB suntik 3 bulan lebih banyak yang berpendidikan dasar dikarenakan faktor ekonomi dan budaya sekitar yang masih mempercayai bahwa perempuan tidak perlu sekolah tinggi, sehingga dalam menerima informasi masih kurang dan pengetahuannya masih rendah terutama
Ciptaan disebarluaskan di bawah

Lisensi Creative Commons

Atribusi-NonKomersial-

BerbagiSerupa 4.0 Internasional.

dalam KB termasuk macam-macam alat kontrasepsi, yang mereka tahu kebanyakan hanya $\mathrm{KB}$ yang mereka gunakan saja itupun kebanyakan karena lingkungan sekitar. Akseptor KB suntik yang berpendidikan perguruan tinggi seluruhnya menggunakan suntik 1 bulan dikarenakan pengetahuan mereka jauh lebih baik terhadap alat kontrasepsi lain, merasa cocok dengan suntik 1 bulan, efek samping lebih sedikit dirasakan.

Kemudian, responden yang memiliki pengetahuan kurang $100 \%$ terdapat pada pengguna $\mathrm{KB}$ suntik 3 bulan. Hal ini dikarenakan masih banyak akseptor KB suntik 3 bulan yang berpendidikan dasar dan kurangnya informasi yang mereka miliki. Akseptor KB suntik 3 bulan kurang mengetahui alat kontrasepsi lain selain yang digunakan oleh mereka dan terpengaruh oleh lingkungan sekitar dan mengikuti apa yang dominan di lingkungan sekitar, sebagaimana teori Riyanto (2014, p. 101) mengemukakan bahwa faktor yang mempengaruhi pengetahuan adalah pendidikan, informasi dan tingkatan masing-masing individu berbeda-beda tergantung dari individu itu sendiri.

Responden dengan umur 20-35 tahun $100 \%$ berada pada pengguna KB suntik 3 bulan. Hal ini menunjukan usia 20- 
JOURNAL OF MIDWIFERY CARE :

VOL. 01 NO. 01, DESEMBER 2020

DOI : $10.34305 /$ jmc.v1i1.188
Ciptaan disebarluaskan di bawah

Lisensi Creative Commons

Atribusi-NonKomersial-

BerbagiSerupa 4.0 Internasional.
35 tahun merupakan usia reproduksi sehat, dan dari hasil penelitian pada usia 20-35 tahun lebih banyak menggunakan KB suntik daripada alat kontrasepsi lain dikarenakan lingkungan sekitar, ketakutan akan alat kontrasepsi lain, kurangnya pengetahuan, dan meyakini bahwa KB suntik yang paling praktis dibandingkan dengan alat kontrasepsi lain, pada usia 20-35 tahun KB suntik 3 bulan dianggap paling pas jangka waktu dalam kunjungan ulangnya.

Dari hasil penelitian juga didapatkan bahwa pada usia 20-35 tahun adalah umur untuk menjarangkan kehamilan bagi mereka yang sudah mempunyai anak dan berniat untuk mempunyai anak kembali. Departemen Kesehatan Republik Indonesia membagi kelompok umur untuk akseptor KB menjadi dua kategori yaitu umur $<20$ atau $>35$ tahun, umur 20-35 tahun. Umur $<20$ tahun atau umur $>35$ tahun adalah usia untuk menunda kehamilan, umur 20-35 tahun untuk menjarangkan kehamilan.

Menurut Wiknjosastro H (2009, p. 23) umur sering dikaitkan dengan pengalaman, pengalaman merupakan salah satu faktor yang dapat mempengaruhi pengetahuan yang berkaitan dengan umur dan pendidikan setiap orang. Semakin bertambahnya umur dan pendidikan yang tinggi maka pengetahuan dan pengalaman seseorang semakin lebih luas.

Selanjutnya dilihat dari hasil penelitian menunjukkan bahwa akseptor KB suntik sebagian besar didukung oleh suaminya untuk mengikuti program KB suntik ini, sehingga para ibu bisa tenang dan tanpa tekanan apapun dalam menggunakan KB suntik tersebut dan karena saran dari suami pula untuk menggunakan KB suntik karena kepraktisannya daripada alat kontrasepsi lain.

\section{Kesimpulan}

Faktor predisposisi tingginya pengguna $\mathrm{KB}$ suntik pada pasangan usia subur di Desa Cihideung Hilir Kecamatan Cidahu Kabupaten Kuningan Tahun 2019 sebagian besar berada pada kelompok pendidikan dasar, pengetahuan kurang, didominasi oleh kelompok umur 20-35 tahun, serta sebagian besar mendapat dukungan suami.

\section{Saran}

Petugas lapangan KB lebih mengoptimalkan sosialisasi khususnya dalam program $\mathrm{KB}$ sehingga akseptor $\mathrm{KB}$ baru tidak mengalami kekeliruan dan hanya mendapatkan informasi dari masyarakat sekitar saja. 
JOURNAL OF MIDWIFERY CARE :

VOL. 01 NO. 01, DESEMBER 2020

DOI : 10.34305/jmc.v1i1.188
Ciptaan disebarluaskan di bawah

Lisensi Creative Commons

Atribusi-NonKomersial-

BerbagiSerupa 4.0 Internasional.

\section{Daftar Pustaka}

Anggraini, Y., M. (2011). Pelayanan Keluarga Berencana. Rohima Press.

BKBPK. (n.d.). Laju Pertumbuhan Penduduk Jawa Barat.

Dinas Kesehatan Kabupaten Kuningan. (2017). Profil Kesehatan Kabupaten Kuningan.

https://dinkes.kuningankab.go.id/

Efendi, Ferry, \& Makhfud. (2009). Keperawatan Kesehatan Komunitas Teori dan Praktik dalam Keperawatan. Salemba Medika.

Esra. (2017). Gambaran Faktor-Faktor Yang Mempengaruhi Penyebab Tingginya Akseptor KB Suntik Di Desa Lagasa Kecamatan Duruka Kabupaten Muna.

Handayani, S. (2010). Buku Ajar Pelayanan Keluarga Berencana. Pustaka Rihama.

Hartanto, H. (2010). Keluarga Berencana dan Kontrasepsi. Pustaka Sinar Harapan.

Hurlock, E. B. (2008). Psikologi Perkembangan Suatu Pendekatan Sepanjang Rentang Kehidupan. Erlangga.

Kurniawan, T. (2016). Faktor-Faktor Yang Mempengaruhi Pemilihan Alat Kontrasepsi Suntik Di Wilayah Kerja Puskesmas Sungai Bakau Kecil Kecamatan Mempawah Timur Kabupaten Mempawah. JURNAL PRONERS 3(1).
Notoatmodjo, S. (2012). Metodologi Penelitian Kesehatan. Rhineka Cipta.

Nugroho, T., \& Utama I.B. (2014). Masalah Kesehatan Reproduksi Wanita. Nuha Medika.

Purba. (2009). Kesehatan Reproduksi Dan Kontrasepsi. Trans Info Media (TIM).

Rastyawati, A. (2011). Pelayanan Keluarga Berencana. Salemba Medika.

Regina Mitha Jacobus. (2018). FaktorFaktor Yang Berhubungan Dengan Penggunaan Alat Kontrasepsi Suntik Pada Akseptor KB di Desa Humbia Kecamatan Tagulandang Selatan Kabupaten Sitaro.

Riskesdas. (2015). Riset Kesehatan Dasar Tahun 2015. Kementerian Kesehatan Republik Indonesia.

Riyanto, A. (2014). Statistik Deskriptif. Nuha Medika.

Runjati, \& Syahrial Umar. (2018). Kebidanan Teori Dan Asuhan Volume 2. Buku Kedokteran EGC.

SDKI. (n.d.). Survei Demografi Kesehatan Indonesia. Badan Kependudukan dan Keluarga Berencana Indonesia.

Wawan, A., \& Dewi, M. (2010). Teori \& Pengukuran Pengetahuan Sikap Dan Prilaku Manusia. Nuha Medika.

Wiknjosastro H. (2009). Ilmu Kebidanan. Edisi Ke-4 Cetakan Ke-2. Yayasan Bina Pustaka Sarwono Prawirohardjo. 